\title{
Editorial - Revista Neurociências
}

É um enorme prazer comunicar a todos que a Revista Neurociências passará a ser publicada segundo novas e modernas regras e concepções editoriais. Foi um longo trabalho levado adiante pela Profa. Dra. Luciane BC Carvalho e pela equipe responsável pelo Portal de Periódicos da Unifesp Maria Eduarda Puga, Andreia Carmo, Fabio Luis Falchi de Magalhaes, Flavio Castro.

Hoje a Revista conta com a submissão online através da plataforma OJS3, permitindo que os autores rapidamente disponibilizem os artigos para revisão. 0 trabalho dos revisores, sempre árduo e de imensurável importância, também ficou mais amigável e rápido.

Uma característica importante dessa nova etapa é a política de fluxo contínuo de publicações. A tecnologia veio para todos e para tudo. Embora o formato impresso ainda seja útil, cada vez mais os leitores utilizam mídias digitais para acessarem conteúdo científico, havendo uma grande variedade de formatos necessários para atender às demandas de também grande número de equipamentos disponíveis. Assim, a formatação deverá se adaptar ao que impõe a mídia em uso pelo "consumidor de informação". 
Nesse sentido o volume passa a ter caráter virtual, favorecendo a divulgação, cuja marca de existência também é virtual: o DOI (Digital Object Identifier).

Todas essas mudanças trouxeram maior celeridade ao processo de publicação, permitindo que os artigos sejam disponibilizados rapidamente ao público.

Agradecemos imensamente os autores e revisores que tornaram a Revista Neurociências conhecida nacionalmente, propiciando publicações bastante citadas e importantes para o que requer nossas necessidades de informação no campo das neurociências e saúde.

Os Editores da Revista Neurociências e a Disciplina de Neurologia da Escola Paulista de Medicina expressam particular agradecimento e reconhecimento a Magnífica Reitora Profa. Dra. Soraya Smailli por nos convidar a participar desse projeto e pelo esforço em dar materialidade ao que anseiam e sonham os que se dedicam à ciência neste país.

\section{Gilmar Fernandes do Prado}

Editor Chefe

Escola Paulista de Medicina (EPM), Universidade Federal de São Paulo (Unifesp), São Paulo-SP, Brasil. 